University of Massachusetts Amherst

ScholarWorks@UMass Amherst

Women, Gender, Sexuality Studies Faculty

Publication Series

Women, Gender, Sexuality Studies

2018

\title{
Fragmented Forests, Fractured Lives: Ethno-territorial Struggles and Development in the Pacific Lowlands of Colombia
}

Kiran Asher

University of Massachusetts Amherst, kasher@umass.edu

Follow this and additional works at: https://scholarworks.umass.edu/wost_faculty_pubs

\section{Recommended Citation}

Asher, Kiran, "Fragmented Forests, Fractured Lives: Ethno-territorial Struggles and Development in the Pacific Lowlands of Colombia" (2018). Antipode. 16.

https://doi.org/10.1111/anti.12470

This Article is brought to you for free and open access by the Women, Gender, Sexuality Studies at ScholarWorks@UMass Amherst. It has been accepted for inclusion in Women, Gender, Sexuality Studies Faculty Publication Series by an authorized administrator of ScholarWorks@UMass Amherst. For more information, please contact scholarworks@library.umass.edu. 


\title{
Fragmented Forests, Fractured Lives: Ethno-territorial Struggles and Development in the Pacific Lowlands of Colombia
}

Kiran Asher, Department of Women, Gender, Sexuality Studies, University of

Massachusetts, Amherst, MA 01003, kasher@umass.edu

For special issue on "Political Forests"

\begin{abstract}
The culturally and ecologically diverse Pacific lowlands of Colombia are both the locus and product of key political economic and cultural political conjunctures. Twenty-five years after they emerged in their current form, Afro-Colombian ethnic and territorial struggles have become important icons of resistance to development and struggles for social change. But in Colombia as in other parts of the world, the rapid and violent expansion of capitalist accumulation and state power have had devastating consequences for the regions forests and communities - literally and epistemically fragmenting both.

Based on long-term fieldwork, this paper examines the ongoing and contentious coproduction of the Colombian Pacific region amidst the increasingly violent forces of neoliberal governmentality in the $21^{\text {st }}$ century. It shows that the Pacific lowlands are an example of "political forests" in the sense that they are a contested site and product of AfroColombian cultural politics and state territorialization.
\end{abstract}

Keywords: Political forests, ethnic and territorial struggles, Afro-Colombian cultural politics

The densely forested Colombian Pacific, or Chocó region, extends some 1300 kilometers along the country's western perimeter, from the border with Panama in the north to that of Ecuador in the south. The variety of ecosystems (coral reefs, mangroves, rock and sandy beaches, coastal forests, highland and lowland tropical moist forests), and exceptionally high numbers of plant and animal species (many of them endemic) make it one of the world's "biodiversity hotspots."

The resource-rich region and its people have been connected in varying and uneven ways to the regional and global political economy since colonial times. The four coastal departments that make up the region-Chocó, Valle del Cauca, Cauca and Nariño — are home to a large percentage of the country's Afro-descendent population, whose ancestors were brought as slaves to work in the placer mines; today, Afro-Colombians make up $90 \%$ of the 
region's inhabitants. ${ }^{1}$ Since the Spanish occupation of the region in the late 13 th century, gold and other precious metals, tagua (vegetable ivory), timber, fish, oil, and natural gas have been key exchange commodities. Yet the Chocó (and other regions, such as the Amazon) figured as geographically "isolated," economically "marginal," and culturally "backward" tierras baldias (empty lands) in the national imaginary and laws of modern Colombia.

Such representations have not gone uncontested: black resistance and organizing date back to the colonial era. At the close of 20th century, the processes of territorialization and subject formation became particularly intense as state forces and social movements made competing claims over the Pacific region. This culturally and ecologically diverse forested region then is both the locus and product of key political economic and cultural political conjunctures catalyzed in part by Colombia's 1991 Constitution.

In the 1990s state formation and capitalist globalization appeared in neoliberal guises and acquired "environmentally sustainable" and "culturally sensitive" hues in the Colombian Pacific as in many other parts of the world. Many sectors of the black movement, including women, resisted these developments and claimed territorial autonomy over their ethnic homeland. Paradoxically, however, "neoliberal conservation” (Devine and Baca, this volume) and "neoliberal multiculturalism" (Rivera-Cusicanqui 2012) shaped both Afro-Colombian demands and state territorialization. ${ }^{2}$ By the turn of the century, the green hues of economic and environmental changes were increasingly stained with the red of violence associated with the twin wars against "drugs" and "terror," intensified resource extraction, and expanding

\footnotetext{
${ }^{1}$ Demographic data on what percentage of the country or of the Pacific region is "black" is highly unreliable and varies significantly. The census conducted in 1991 was declared so full of errors that the Colombian state reformulated its census forms and collected new census statistics. According to 1993 national data the Chocó biogeographic region has a population of 2.3 million people (a little more than $6 \%$ of the total population of Colombia) of which $90 \%$ are Afro-Colombian and $4 \%$ Indigenous. According to the 2005 census $10.6 \%$ of Colombia's population, just under 4.3 million people, identified themselves as Afro-Colombian. Afro-Colombian activists and their supporters claim that as many as $21-25 \%$ of Colombians are Afro-descendants and increasingly urban. Since 1996 a research project at the Universidad del Valle in Cali has been focusing on the social and ethno-racial dynamics of Afro-Colombians. See Barbary and Urrea (2004) for the results of this work. DANE (www.dane.gov.co), the Colombian agency responsible for the national census and collecting demographic data, has numerous papers discussing the problem of accounting for "blacks" in the country.

${ }^{2}$ The term is attributed to Charlie Hale (2002). But as he acknowledges, his concept of the "el indio permitido" (translatable as "the imaginable indigenous entity" derives from Silvia Rivera-Cusicanqui's discussion of indigenous politics in Bolivia.
} 
state presence. These violent forces had devastating consequences for the region's forests and communities_-literally and epistemically fragmenting both. ${ }^{3}$

Indigenous and Afro-Colombian struggles for ethnic and territorial autonomy, and more recently against violent death and displacement, have gained remarkable national and global visibility. ${ }^{4}$ Afro-Colombians in particular have become important icons of "postdevelopment" alternatives. Their cultural practices have been lauded as examples of placebased political ontologies opposed to liberal state power and capitalist accumulation (Escobar 1995, 2008, 2010, 2018; Oslender 2016). Rather less attention has been given to how AfroColombian struggles, state power, and neoliberal development shape each other in paradoxical and uneven ways (Asher 2009; Asher and Ojeda 2009; Ng'weno 2007). This paper examines the ongoing and contentious co-production of the Colombian Pacific region amidst the increasingly violent forces of neoliberal governmentality in the $21^{\text {st }}$ century.

The intertwined dynamics of development and resistance in the Pacific lowlands reflect and refract Peluso and Vandergeest's (2001) insights concerning “political forests." Discussing forestry and state-making in Southeast Asia, they note that "forests" and "customary rights" are constructed rather than natural or universal categories, and vary across regions. They also observe how regional variations depend on the relative hegemony of local forest departments, the potential value of forests and natural resources to the regional political economy (and these days, to the global economy), and the power of native rights discourses. However, as Devine and Baca discuss in the introduction to this volume, Peluso and Vandergeest's later work (2011; Vandergeest and Peluso 2015) has inspired extensive research on the politics of forests or "nature," state-making, and socio-cultural struggles. This

\footnotetext{
${ }^{3}$ The Washington Office on Latin America (www.wola.org) provides regular and extensive coverage of the violent conflict in Colombia, the involvement of the United States in it, and of the impacts of the conflict on local communities, especially indigenous and black groups. While not the only international advocate and ally of these communities and their struggles, it has maintained consistent connections with them on the ground.

${ }^{4}$ For example, in 2018 Francia Márquez became the second Afro-Colombian woman to win the Goldman Environmental Prize https://www.goldmanprize.org/recipient/francia-marquez/
} 
body of work (Asher 2009; Asher and Ojeda 2009; Elmhirst 2011; Li 2007; Matthews 2011; Ng'weno 2007; Peluso and Purwanto 2018; Wolford 2010) expands the insights about "political forests" in various ways.

Two of these are particularly central to this paper. First, "forests" as political categories and socio-natural spaces are not solely products of a state's territorializing power. Rather they are contentiously co-produced by state and non-state entities as part of complex, contradictory, and power-laden processes of nation-building and subject formation. Furthermore, diverse "natures" and resources become political categories and serve to normalize and disrupt the institutions, power, and violence of modern nation-states in various ways: as spaces of scientific or economic value, of counterinsurgency or illegal extraction, of biodiversity conservation, and of much more. That is, what counts as "forests," how they emerge, and what "political" functions they serve varies over space and time. Awareness of the spatial, ecological, and functional diversity of forests also serve as reminders that neither communities nor states are homogeneous categories. Even communities of the "same" group are heterogeneous in socio-demographic terms (gender, age, occupation, class, displacement histories, etc.), and different sectors of social movements have different ideological and political strategies. Similarly neither state programs nor development policies are unitary in their logics and execution. In short, the contentious co-production of political forests depends on the manifold interactions between diverse and multifaceted state and non-state entities.

The biodiverse Pacific lowlands are an example of "political forests" in the sense that they are a contested site and product of Afro-Colombian cultural politics and state territorialization. This paper focuses on the dynamics of the former during the so-called "post-conflict" moment in Colombia when the violence of armed conflict and the epistemic violence of neoliberal governmentality were becoming endemic in the region. It draws on my twenty-five years of research in the Chocó and particularly from my ethnographic fieldwork 
and conversations with black activists in 2008 and $2011 .^{5}$ It examines and compares the ongoing efforts of Afro-Colombian groups to assert ethno-territorial claims in the context of violence in two areas of the southwestern Pacific coast-Buenaventura and Tumaco. Marked by internal differences and over-determined links to the state's development agenda, these struggles alert us to the limits of understanding socio-spatial dynamics in binary terms such as state/non-state, culture/nature, development/resistance, modernity/tradition, materiality/meaning, or even violence/peace.

Ongoing research on Afro-Colombian movements including this paper shows how they are not only struggles over material resources of land and livelihoods but also attempts to broaden the meanings of ethnicity, territory, and politics. Attention to the inter-animation of black ethno-territorial struggles and neoliberal governance in the Pacific lowlands necessarily broadens what counts as political forests and focuses attention on their "contested coproduction" (Devine and Baca, this volume) within particular political economic conjunctures. Acknowledging that subjects and space are fluid and contingent products of contentious interactions between state and non-state entities is the broader point of this paper, and one that I flesh out in the concluding remarks. ${ }^{6}$

\section{Black cultural politics in the Colombian Pacific from 1990s-2010}

Black organizing efforts in the $20^{\text {th }}$ century were greatly heterogeneous reflecting the diversity of class, occupation, political ideology, and local and regional histories of black communities themselves. ${ }^{7}$ They included urban groups fighting racism; cultural groups;

\footnotetext{
${ }^{5} \mathrm{My}$ work and this paper are also grounded in prior work on the territorial and aquatic politics of black movements. Elsewhere, I engage the debates about how relational ontologies and cosmovisions of Afro-Colombian social movements represent "post-development" - "decolonial" alternatives to colonial modernity.

${ }^{6}$ Indeed this point is a subset of critical debates in a variety of fields such as feminist and postcolonial geography and feminist science and technology studies to name a few, about how subjects and space are produced through and embedded within human-nonhuman interactions. I regret that I cannot engage these debates here but their insights implicitly underlie my work.

${ }^{7}$ In the 1990s, in addition to a substantial representation of blacks in metropolitan centers (Bogotá, Medellin and Cali), there were six regions of important black presence in Colombia: the Atlantic/Caribbean coast; the Magdalena river valley, the
} 
peasant and women's collectives organized around logging, mining, fishing, and other subsistence activities; and community councils. The constitutional reform process in the 1980s and the adoption of a new national Constitution in 1991 opened new spaces for black organizing.

The 1991 Constitution is an ambitious political charter that brought extensive and contradictory changes to the Pacific region. Neoliberal economic-growth initiatives sought to intensify infrastructure development and natural-resource extraction to "modernize" the region and "integrate" it with the nation. The region was simultaneously the focal point of national and international environmental-conservation efforts to protect and sustainably develop its "green gold." Extensive efforts by social movements and the new Constitution's official multiculturalism also led to the legal recognition of the ethnic and territorial rights of indigenous and black communities. ${ }^{8}$ But this purported multiculturalism hides widespread ambivalence towards black rights. Under the new constitution, indigenous groups were granted greater administrative, financial, and territorial autonomy. Rights for black communities were outlined in the brief and ambiguously worded Artículo Transitorio 55 (AT 55, Transitory Article 55), which stipulates collective land titles for riverine black communities in the Pacific. After two years of intense black mobilization, AT 55 became Law 70 in 1993.

The term "Afro-Colombian" first came into wide circulation at this time, as more Colombians of African descent sought a name that highlighted both sides of their identity. A variety of organizations and coalitions emerged during the process that led to Law 70 of

Cauca and Patía river valleys in the Andean region; the San Andrés and Providencia archipelagos (where English predominates); and the rural riparian zones of the Pacific Littoral.

${ }^{8}$ Ethno-racial designations in Colombia are fluid and contested. In the early 1990s, the term "black communities" came into use as a cultural political identity and one that denotes specific legal and policy meaning. In this article, I use the terms "black" and "Afro-Colombian" interchangeably. I also use the term "Afro-descendant," which came into use (along with and "Afro-Latin" people) at the turn of the 21 st century, roughly around the time of the 2002 UN Conference against Racism in Durban. 
1993. ${ }^{9}$ Among the most well-known groups to emerge in this time was the Proceso de Comunidades Negras (PCN, the Process of Black Communities). The PCN's base was in the southwestern state of Valle del Cauca, but it brought together black activists and intellectuals from the other southwestern states of Cauca and Nariño, the Caribbean region, and the Colombian capital Bogotá. Unlike other groups and especially those linked to formal political parties, the PCN was less interested in exploiting the potential opportunities of the country's economic and political opening than in creating a broad movement for black autonomy (Grueso et al. 1998). Asserting that their culture and livelihoods depended on the sustainable use of the region's forests and natural resources, they organized around the call for AfroColombian "identity, territory, and autonomy." They mobilized peasants, artisanal fisherfolks, loggers, and miners as well as students and urban activists. Like many other groups in Latin America, and like indigenous groups in Colombia, the PCN and other black groups linked their bid for territorial rights with national and international environmental conservation efforts (Asher 2009; Asher and Ojeda 2009; Leal 2015; Rivas 2004; Wilshusen 2003).

Not surprisingly, the goal of establishing autonomous territorial control over the Pacific was not successful. Yet the passage of Law 70 was an historic victory for black communities. Even as the first collective land titles were handed out in 1997, however, black groups began to be displaced from the Pacific in vast numbers because of the dramatic onset of violent conflict. Black communities became frequent targets of intimidation, brutalization, and murder (UNHCR 2010).

\footnotetext{
${ }^{9}$ Key among them were OBAPO (Organization of Popular Neighborhoods and Black Communities of the Chocó) and ACIA (the United Peasant Association of the Atrato River), both in the northern Department of Chocó (the only state with a majority black population, and not to be confused with the biogeographic region of the same name). While OBAPO mobilized shanty-dwellers in the departmental capital Quibdó and coastal communities of the Chocó, ACIA focused on organizing black riverine peasants. Initially these Chocoan groups asserted the primacy of ethnic and territorial rights to break into the clientelist stronghold of department politics dominated by black elites. Later they continued their struggles by linking up with electoral politics and political parties. Further south, many rural, riverine community organizations gained force with the help of the Catholic Church and social welfare entities.
} 
In 2000, the Colombian government and the Clinton administration began to implement Plan Colombia. Initially proposed as a US\$1.3 billion "aid package" and anti-drug campaign, Plan Colombia soon expanded into an armed offensive against guerillas. During the two terms of Alvaro Uribe's presidency (2002-2010), the "war on drugs" morphed into the "war on terror". Neither the anti-narcotic nor the anti-guerilla tactics proved effective, but the intervention served to intensify the conflict between drug traffickers, guerillas, paramilitary forces, and the Colombian army. Afro-Colombians and indigenous communities were caught in the crossfire. By 2005, an estimated two million Afro-Colombians, or close to one in three, had been involuntarily displaced from their homes. ${ }^{10}$ A demographic minority, Afro-Colombians make up the majority of internally displaced persons (IDPs) in the country. Afro-Colombians faced homelessness, loss of lands, an exacerbation of existing inequalities, and renewed forms of social exclusion.

Many other political and environmental gains of the 1990s were rolled back during Uribe's presidency. The expansion of neoliberal policies went hand in hand with armed violence and served to increase the presence of market forces and the state in the region (Oslender 2007, 2016). Large infrastructure projects such as the ones in Buenaventura that I describe below literally paved the way for accelerated resource extraction on lands that were "grabbed" for capitalist accumulation, legally or illegally, but almost always violently. Defoliant chemicals were used over large areas, damaging forests and destroying food crops alongside the coca and marijuana they were meant to eradicate. Areas cleared of vegetation, if not immediately replanted with drugs, were exploited for illegal logging, mining, and agroindustrial projects. African oil palm plantations grew dramatically in number as a demand for

\footnotetext{
${ }^{10}$ The Consultancy on Human Rights and Displacement (Consultoría para los Derechos Humanos y Desplazamiento, CODHES), one of the most respected and authoritative non-governmental sources on Internally Displaced Persons (IDPs) in Colombia publishes regular bulletins (available at www.codhes.org) with updated figures on IDPs and their plight. It estimates that between 1995 and 2005 three million people were forced to flee their homes because of violence related to armed struggles or disputes over territory and resources (CODHES 2006). IDPs tend to belong disproportionately to minority groups, with Afro-Colombians accounting for around 33\% of the 412,500 persons displaced during 2002 (Human Rights Watch 2005). During the first semester of 2006, $12 \%$ of the total number of those displaced were from minority groups (CODHES 2006: 3). A 2011 CODHES report notes that by 2010 there were almost 5 million IDPs in Colombia.
} 
biofuels developed (Cardenas 2012). These dynamics echo many of the counterinsurgency tactics and resource wars discussed by Peluso and Vandergeest (2011).

As the accelerating conflict and its effects gained international visibility and attention, so did black struggles (Asher 2017). Afro-Colombian movements made alliances abroad with a wide range of non-governmental organizations, advocacy groups and academics concerned with human rights, anti-racism, anti-globalization, and social and environmental justice such as the Washington Office on Latin America (WOLA) and Via Campesina. They also connected with the black diaspora, Afro-Latino groups in the Americas, and particularly with the Black Caucus of the US Congress to help bring attention to the effects of US policy on Afro-Colombian communities. As was the case with many social movements and civic protests in Latin America, the strategies of black movements within Colombia also expanded to participate in what Alvarez et al. call the neoliberal "Civil Society Agenda" (2017:2). Black organizations and leaders began to engage more directly in electoral politics and to form alliances with development institutions and projects. In the 1990s, some black groups and especially the PCN had sought to organize Afro-Colombians beyond the struggle for law and rights. However, within the new conjunctures of violence, the call for ethno-cultural "human rights" and the right of displaced black communities (Afro-desplazados) to return to their ancestral lands became key rallying points. The PCN amended its motto from "Identity, Territory, and Autonomy" to "Identity, Territory, Dignity, and Life" to highlight the plight of the fractured lives of Afro-descendant peoples and their fragmenting territories in the biodiverse Pacific (Asher 2017).

Nearing the end of the first decade of the 21 st century, the stalled peace talks with the guerrillas resumed and a "post-conflict" moment was ostensibly on Colombia's horizon. New legislation, such as the Law of Justice and Peace (Law 975 of 2005) and the Victims and Land Restitution law (Law 1448 of 2011), was passed as part of the "transitional justice" 
process to demobilize armed groups and restitute the rights of displaced communities

(Martínez Cortés 2013). As with so many of Colombia's laws, however, these ambitious laws and the 2009 rulings of the Constitutional Court (Auto 004 and Auto 005) protecting the fundamental rights of indigenous and Afro-Colombian communities were more rhetorical than real (Velez 2014; Martínez Córtez 2013). ${ }^{11}$ In the Pacific, the vortex of violence abated, to be replaced by a more chronic and entrenched form of conflict. When peace talks resumed in Havana in 2016, attention to ethnic issues and the suffering of black communities were conspicuously absent. It took renewed mobilization by black groups to incorporate a section on ethnic and black rights into the 2016 Peace Accords.

Amidst continued displacement, graphic femicides, and other atrocities, black leaders and communities began returning to the region and shifting their attention from strictly humanitarian and crisis-management approaches to the broader goals of more sustainable cultural and ecological alternatives in their territories. ${ }^{12}$ But as in earlier times, black struggles were heterogeneous at best and split and splintered at worst over how to strive for genuine social and environmental justice. Adding to these difficulties was the fact that the market forces and state logics that black movements had tried to hold at bay in the 1990s were becoming entrenched in the Pacific. Resource extraction and commodity trade (licit and illicit) were dominating the economy, and ethno-territorial struggles were increasingly tied to the institutionalized development agenda. But the form, extent, and outcome of the contentious linkages between resistance and development varied even within the southwestern Pacific region, as I discuss below.

\section{The PCN's ethno-territorial struggles in the "post-conflict" period}

\footnotetext{
${ }^{11}$ Among the many inadequacies and problems with these attempts at transitional justice is that several members of the Colombian congress have been found to have links military officers and paramilitaries, and the state bears responsibility for killing its citizens. Furthermore, the laws gives impunity to many without addressing human right abuses.

${ }^{12}$ For a discussion of femicides in Buenaventura see http://www.wola.org/highlight/impunity_reigns_in_cases_of_femicide_in_buenaventura_colombia. Several women, feminists and feminist groups in the region are actively writing about and addressing these femicides that are receiving less academic and advocacy attention than the issue of violence at large. On women, gender, and forced displacement in Colombia at large see Meertens (2010) and Defensoría del Pueblo and the International Organization for Migration (2008).
} 
Buenaventura is a major port city in the southwestern department of Valle del Cauca a few hours' drive over the western cordillera from Cali, the departmental capital. It is not just an important coastal gateway from Colombia to the world, but also an important cultural, political, and economic hub for the riverine communities that form part of the municipality of Buenaventura. Since the mobilization process that led up to Law 70 of 1993, it has been the regional base of the PCN and the many organizations (from Anchicayá, Calima, Cajambre, Naya, Raposo, Yurumanguí and other rivers) that form part of it.

In November 2008, I returned to Buenaventura after almost a decade. The sights and sounds of development and militarized state presence were everywhere along the once familiar road from Cali. The highway from Cali to the coast, winding along the steep mountain slopes, was being widened from two to four lanes. The violence that had made travel along the road extremely dangerous in the last ten years had abated but not disappeared. Landslides and military checkpoints lined the road with almost equal density. The landscape abutting the road bore the scars of development: of the once-dense forests there were only charred remnants interspersed with Cecropia and other scraggly secondary growth. The once-clear river was filled with sediment from the road construction, as well as illegal logging and gold mining. At the entrance of town a huge new department store, $E l$ Exito, which is part of a national chain had almost entirely displaced little shops and ambulatory vendors.

Change was also evident in the PCN. The large two-story building that housed its office had been purchased with the money from the 2004 Goldman Environmental Prize. http://www.goldmanprize.org/recipient/libia-grueso/. As noted in the previous section, the PCN was one of many sectors of Afro-Colombian organizing to emerge in the 1990s. The organization played a key role within the movement and had become one of the most visible faces of Afro-Colombian struggles outside Colombia. Many academics, myself included, had 
nominated them for the Goldman Prize, highlighting their struggles for their lives, livelihoods and lands along with their efforts to maintain sustainable alternatives to extraction-based development and agribusinesses.

These struggles continued in the midst of threats, killings, and displacements. Lauding this "black environmentalism," the Goldman Environmental Prize was awarded in 2004 to Libia Grueso as a co-founder and representative of the PCN. ${ }^{13}$ Enrique Leff, a noted Mexican social scientist and coordinator of the Environmental Training Network for Latin America and the Caribbean, United Nations Environment Programme, notes that "Grueso and the PCN have been the most effective in putting into practice an innovative vision and strategy for sustainable development based on the marriage of ecology and culture." (http://www.goldmanprize.org/recipient/libia-grueso/). Arturo Escobar (2008, 2010), the most well-known of the PCN's supporters, characterizes its work as a decolonization project rooted in sustainable ancestral practices of economic development and self-government.

The 2004 award could hardly have been better deserved and brought much-needed national and international recognition to the PCN. The "marriage of ecology and culture,", however, has been filled with tensions and contradictions since its inception (Asher 2009). Practicing effective self-government in the vast and diverse Pacific region posed immense logistical and political challenges. These included reaching dispersed and heterogeneous black communities (in terms of geographies, ideologies, genders, class, etc.) and organizing across the internal contradictions or divisions within the black movement. Furthermore, in its bid for territorial autonomy and alternative economies, the PCN sought to avoid overly-close alliances with mainstream development and environmental projects. Of course black communities could not function entirely independent of the state, NGO, and development entities and had to negotiate with them over the region's future. But such negotiations were

\footnotetext{
13 The PCN was nominated for the Goldman prize twice. In 2003, they were the semi-finalists. The awarding of the prize to an individual rather than a group is in tension with the PCN's focus on black collective struggles. It is beyond the scope of this paper to explore this particular contradiction that appears repeatedly in social struggles.
} 
over-determined especially when the decentralization and territorialization policies of the 1990s paradoxically led to a greater state presence in the region (Asher and Ojeda 2009).

Such "state territorialization" (Peluso and Vandergeest 2011) deepened during the civil war and in the "post-conflict" period. In addition to a stronger military presence, there was a proliferation of state-sponsored and internationally funded projects to promote peace, progress, and sustainability. Thus, while critical of this neoliberal civil society agenda and the institutionalized- democratic politics and development that characterizes it, the PCN had to engage with it more than ever before. This engagement took multiple forms as I learnt from conversations and visits in 2008 and 2011.

On the day of my visit to the PCN office in November 2008, the office was abuzz with the hum of computers and the banter of students. Many of them were from the surrounding riverine communities who were enrolled in the Buenaventura branches of public and private universities. They were working on GIS maps to demarcate collective lands for titling and to make natural resource management plans, both of which were a prerequisite for implementing territorial rights. This project was also part of their academic course of study.

But new and younger activists were not the only ones working with state-sponsored research and community development projects. In the next few days (and during subsequent visits in 2011), I spoke to several core PCN members who had been staunch advocates of autonomous development in the 1990s. Among them was an activist who had been working with various state social welfare programs since the 1990s and was currently working on a project with the local public university focusing on resettling communities from low-lying neighborhoods in Buenaventura. ${ }^{14}$ One young student was critiquing this university-managed project. In what seemed like an echo of conversations of the mid 1990s, he was arguing that

\footnotetext{
${ }^{14}$ Writing about these movements over a decade ago, I used to give real names to the voices of Afro-Colombians given that black communities had long been invisibilized in the country. Now I feel compelled to withhold the names or use pseudonyms for many of the activists out of concern for their safety. I name those whose private opinions are already wellknown in other public fora.
} 
the university (as a public institution) and the PCN (as a social movement) should be resisting institutionalized versions of implementing black rights and striving for more genuine and radical cultural and territorial visions of development. The older PCN member responded that the PCN was better off working from the inside to see what was going on within institutions. Such a stance was a distinct departure from the PCN's earlier opposition to working overtly with state-sponsored programs.

This outlook was echoed by another PCN stalwart, who in the 1990s had adamantly refused to engage with development and research projects associated with formal institutions. He was now employed at a local public university after having received a degree in Sociology. He went on to note that the PCN was "in his blood," but his job was not allowing him enough time and energy for cultural political activism. He spoke of the need for strategic alliances, including working within institutions as a way to keep one's finger "on the pulse" of public policy.

A couple of days later I spoke to another core PCN member and the head of their human rights team. Chucho [pseudonym] was on his way to a meeting at the mayor's office to discuss a conflict that had emerged in the Rio Raposo area, his place of origin. He noted that the PCN and the black organizing process were even more stretched than they had been 15 years ago. Black organizations had to work on many fronts: addressing the issues of displacement and human rights violations, responding to calls to participate in institutional politics and projects, and connecting with the large and growing numbers of black communities in urban areas with little prior knowledge or involvement with broader ethnocultural and territorial struggles. The challenge of responding to these multiple demands was compounded by internal differences within Afro-Colombian movements over how best to address their concerns and how to participate in institutional initiatives. These differences echoed those of the past, as did the power struggles over who should serve as members of 
community councils (Consejos Communitarios), as official black spokespersons on the boards of corporations, and as candidates for local offices. In another departure from the PCN's past autonomous stance, Chucho was hopeful that engaging with outsiders would help black struggles address their internal divisions as well as expand the narrow forms of institutionalized participation and unequal neoliberal development.

On my next visit to Buenaventura, in June 2011, it did not seem that such hope had borne fruit. Both the internal divisions within black movements and the external challenges of institutionalized neoliberal development had deepened. Austin Zeiderman's (2016) detailed and nuanced analysis of popular black politics and territorial conflict under conditions of highly unequal development in this port city is representative of broader dynamics in the region. The rising importance of the port for the national economy has made the lives of the city's inhabitants increasing precarious in economic, ecological, and political terms. More merchandise was being exported from Buenaventura than anywhere else in Colombia. Despite the increasing volume of trade and plans to expand the port, dock workers, even unionized ones, were facing unemployment or were being harassed, threatened, disappeared, or killed (Nicholls and Sánchez-Garzoli 2011). Communities living along the seacoast are being displaced as a consequence of port expansion or forcibly relocated in the name of managing the risk of floods due to the effects of climate change.

From the balcony of one of the many new hotels mushrooming on the oceanfront, I got a clear glimpse of this scenario. Large ships were coming into port, bearing containers with names such as China Shipping Lines, Hanjin and Hapag-Lloyd. To the left of the hotel were the classic wooden stilt houses of coastal fisher folk. A broad swath of sand (probably the sediments dredged from the shipping canals) was being unloaded next to these houses to form a beach and develop the area for tourism. Later in the day at a festival held to celebrate the popular neighborhoods and their culture, I heard that the locals ironically called the 
emerging beach front "Acapulco." These new developments, rising sea levels, and the strategic importance of the coast for the drug trade were poised to relocate the fishing communities and deprive them of their livelihood. Apart from unskilled, low-paid, construction work, few jobs were available to locals. For Afro-Colombian youths - many of whom are orphaned by the armed conflict — the situation was particularly dire. With little or no scope for employment, many are caught in the nets of drug money and endemic violence. Young boys and men are often forced to become drug runners or as scouts for rival gangs. Young girls are targets of rape and sexual violence or are forced into prostitution. Many of these boys and girls do not make it to adulthood as they are brutally murdered at a young age (Nicholls and Sánchez-Garzoli 2011).

Not surprisingly the young PCN activists I spoke to in June 2011 raised the issue of the economic and political precarity of black lives. With us was Rolando Caicedo, a black councilman with close connections to the PCN and the left-wing political party Polo Democrático. Caicedo was seeking the PCN's support for the upcoming municipal elections. The activists were grilling Caicedo about his party's position on economic and ethnic rights issues. They spoke of the need for black youth to have access to affordable education and particularly to "training in human rights" and "entrepreneurial skills" so they could alter economic relations between themselves and Colombia's white and mestizo populations. The women in the group spoke of the PCN's "gender and generation" project to address the rights and needs of women and youth. ${ }^{15}$ This focus on "rights" and "rights-based development" was a sharp contrast with the PCN's earlier rejection of liberal discourses of development and democracy (Grueso et al. 1998). But it parallels Zeiderman's (2016) insight about how the racialized politics of precarity under late liberalism unfold in Buenaventura, viz.

\footnotetext{
${ }^{15}$ It is beyond the scope of this article to do justice to the changing nature of women's organizing and gender dynamics of black struggles. I discuss them elsewhere.
} 
... liberal governance and their multicultural and biopolitical logics of recognition

both enable and constrain efforts to resist displacement and dispossession... (p. 824825)

I raised this issue with Carlos Rosero the charismatic activist, well-known nationally and internationally for his eloquent testimony on Afro-Colombian struggles and blistering critiques of neoliberal development in the Pacific. One of the PCNs most vocal leaders, Rosero faces regular threats to his life and has had to flee abroad numerous times to seek asylum. My encounter with Rosero was serendipitous. Over lunch, Rosero and a PCN compañero remarked that the embodiment (the term he used was "corporalización") of violent conflict was affecting the black agenda profoundly. "With so many killed or displaced, social movements are weaker and leaders coopted. Those of us who resist are few and are getting fewer, and organizing focuses more on projects than politics." AfroColombian communities' current engagement with development initiatives is part of the material effects of such embodiment.

Rosero clarified that "politics" referred to PCN's ethnocultural and territorial cosmovisión, long the basis of their claims for autonomous alternatives. He recalled that in the 1990s such politics, and the alliances between environment and social movements, had managed to stop the construction of an oil pipeline between Cali and Buenaventura, which would have run through ecologically rich and fragile areas. However, both the alliances and the halt to infrastructure projects were short-lived. Remarking on their break with World Wildlife Fund, he noted, "They were among the first NGOs to start working with industry and commercial sectors. They were talking about sustainable development through oil palm cultivation. That's a joke.” Rosero's concern about expanding oil palm plantations and skepticism about the claims of the Roundtable on Sustainable Palm Oil (RSPO) are shared by many in Colombia and beyond (Cárdenas 2012; Silva-Castañeda 2015). 
Rosero (and Libia Grueso, several days later) noted that since 2001 national policies promoting biofuel production (which began appearing after President Uribe's gutting of environmental legislation) had been helping to grab crop lands formerly devoted to subsistence and food production. Members of Grupo Semillas, a Bogotá-based NGO, told me that, "the ecosystemic violence in the entire region is terrible, with local multiple-use livelihoods changing to monocultures everywhere and leading to impoverishment of everything." Such projects and the resulting land grabs (Borras et al. 2011) are being pushed as part of the "green economy." Among them are REDD (Reducing Emissions from Deforestation and Forest Degradation in Developing Countries) projects to address climate change. These projects are promoted by the UN, USAID, and other multilateral entities that contract international NGOs and development consultants for their implementation. But both Rosero and Grueso noted separately that REDD projects have little traction in local communities or positive results for them. ${ }^{16}$ Indeed, none of the communities around Buenaventura and Tumaco I visited had ever heard of REDD.

Black activists, their allies, and others familiar with the dynamics in the region tell the same story: the region and its people were under the shadow of the "monsters" of mining, large infrastructure projects, coca, and oil palms. Rosero and others note that in a context where mining was an immense and unstoppable activity, many local communities — after receiving promises of $10 \%$ of proceeds or concessions-were forced to support it. ${ }^{17}$

Although black communities have gained significant legal rights since the 1990s, these rights are often violated or overridden by a variety of other laws and decrees designed to foster economic growth or implemented in the most minimal ways through technical and apolitical development projects. Often funded through US and European aid packages and

\footnotetext{
16 Set up in 2008 the REDD Monitor (http://www.redd-monitor.org/) provides summaries and reviews of critical perspectives on REDD and REDD+ projects.

17 Targeted at a different audience but feeding this general dynamics are events such as the Feria Internacional de Medio Ambiente (FIMA, http://feriadelmedioambiente.com/index.cfm) held in 2010 and 2016 where shiny booths sponsored by multinational companies showcase mining as the axis of economic development, cite growth rates of 6 to $7 \%$ a year, and argue that it will help modernize and meet the needs of local communities.
} 
contracted to western development firms with few connections to local dynamics, such projects subvert the potential of black struggles as often as they advance them. ${ }^{18}$ Now, as in the mid 1990s, black movements face an over-determined choice: participate in some capacity with these projects or risk complete marginalization from the changes sweeping the region.

Conversations with Jesus and Efrain [pseudonyms] illustrate the nature of such participation. The PCN was the local partner for two USAID- and U.S. State Departmentfunded projects to assist IDPs and victims of violence access their rights. The primary implementing agency, Global Communities (formerly CHF International), describes its goal as strengthening the "capacity of Government of Colombia institutions and other actors to develop tools, systems, and skills that will empower [Global Communities] to fulfill its mandate to resolve land issues and restore land to victims of conflict" (http://www.globalcommunities.org/colombia, accessed October 14, 2016).

Jesus noted that part of the NGO's implementation efforts entailed making local communities aware of the mechanisms of participation and laws available to them to confront mega-development projects. Among these laws are the 1989 Indigenous and Tribal Peoples Convention of the International Labor Organization (also known as ILO 169). Ratified by Colombia in 1991, the Convention requires that the state seek the participation of ethnic communities in any decisions and discussions affecting them. Such participation is further guaranteed by several articles of Law 70 and by international law and the principle of consulta previa or Free and Prior Informed Consent (FPIC), which requires that traditional peoples be consulted and their consent obtained before any project that affects them can

\footnotetext{
18 This USAID fact sheet lists the development projects funded by the US government with Plan Colombia monies. These monies for development are less than $10 \%$ of the aid given to Colombia, and it is illustrative that one of the largest contract is to Chemonics, a private development firm.

https://www.usaid.gov/sites/default/files/Colombia\%20Country\%20Fact\%20Sheet\%20Augst\%202013_USAID_at_a_Glanc e.pdf
} 
proceed. Jesus and Efrain went on to comment that both the means for implementing such principles and the mechanisms for local participation are less clear.

One existing mechanism is the High Level Consultative Commission (CCAN, Commission Consultiva de Alta Nivel), created by decree in 1994. The CCAN has been plagued by controversy since its inception, however, and has frequently been dominated by black politicians and state representatives with little or no connection to the communities for whom they purport to speak (Asher 2009).

Indeed, the cooptation and corruption of black leadership was a matter of grave concern for community members during my visits and remains so for many. The resulting politics of representation are complex and more so in social and political terms than matters of legality. For example, community members elect representatives to local community councils, but many of these representatives resort to corrupt methods to gain their posts. Jesus explained that the structure of the councils — sixty-three across the Pacific coast, sometimes representing just a few hundred citizens each—made it "easy to buy votes."

A particular concern for the PCN and other grassroots movements is that the mechanisms of interlocution and consultation, intended as a tool for defending collective land rights, have often worked against these aims. In practice, the CCAN, community councils and FPIC frequently become administrative and bureaucratic instruments serving the interests of capital and the state rather than black communities. During the Uribe years, the CCAN often fell into line with the administration's neoliberal economic agenda, including the dissolution of the Forest Law and the Second Development Plan. ${ }^{19}$ Strong confrontations between the CCAN and black movements followed. As before, these processes reveal fractures and frictions within black movements about what constitutes culturally appropriate development

${ }^{19}$ See Feb 9, 2011 http://www.lasillavacia.com/historia/el-plan-nacional-de-desarrollo-en-el-laberinto-del-poder-afro-21588, and http://www.lasillavacia.com/historia/3201 
and how best to work towards it. They also reveal the contentious and uneven intertwining of the agendas of ethno-territorial struggles and neoliberal governance. Such unevenness was even more evident in Tumaco.

\section{Tumaco: Projecting Development}

Black activists in the southernmost port town of Tumaco, and their allies share many of the concerns, hopes and inspirations as their counterparts up the coast in Buenaventura. Tumaco is a small port city of 200,000 on Colombia's Pacific coast in the Department of Nariño. Located less than 30 miles north of the Ecuadorian border, the Colombian military has an air and naval base here. Economic, ecological, and political precarity also condition the lives of its predominantly Afro-Colombian residents: eighty-four percent of households live in poverty, environmental degradation (flooding, mangrove destruction, risks of tsunamis, etc.) exacerbated by agro-industry threatens lives and livelihoods, and fumigation and the "war on drugs" in Putumayo in the Amazonian region brought coca production to Tumaco. With coca came more armed entities - those that sought to profit from the trade and those whose job was to eliminate it. In 2000, with the introduction of Plan Colombia, the "war on drugs" morphed into the "war on terror," and Tumaco was caught in the vortex of the country's civil war.

In Bogotá, the Uribe government denied the existence of internal conflict. But during my November 2008 trip to Tumaco the presence of armed forces was as palpable as that of infrastructure development. Many new or refurbished hotels lined the beachfront of the Playa del Morro, a popular destination for Colombian tourists. More were being built. During the day, the blare of music from radios and the shrill voices of daytime soaps on television competed with the noise of construction. Construction runoff combined with tannins from mangroves to turn the emerald green waters of the Pacific Ocean and shoreline to a dark brown-black. 
One morning I saw a drill sergeant leading military exercises on the water's edge. As the tide started to rise, the soldiers piled into military vehicles looking incongruous against the palm trees, palapas, the ocean, and the remains of the previous night's revelry. The green of camouflage was visible everywhere in Tumaco, well beyond the rows of military barracks lining the road from the beach to town.

What PCN's Carlos Rosero called the embodiment of conflict has acute effects in Tumaco. The ubiquitous military presence and endemic violence (Tumaco has one of the highest murder rates in the country) have made black struggles life-threatening. Organizations concerned with the territorial rights of black communities were greatly weakened by the murders of their leaders. A prominent example is Pastoral Social, the charitable arm of the Archdiocese of Medellín, whose regional director Sister Yolanda Cerón was assassinated in 2001. A large number of PCN's leaders were forced to leave the area after receiving death threats, and the PCN has a much smaller presence in Tumaco than in Buenaventura. Outside the city proper, the Tumaco municipality is almost entirely rural, and travel along the rivers to get to the communities is controlled by rival armed forces. The citizens, and especially community leaders, of Tumaco and riverine communities were frequent victims of clashes between the military, guerrillas, paramilitary groups, and drug traffickers.

Black organizing continued but was more dispersed than in the 1990s. The PCN's Nariño chapter (or Palenque) eventually disintegrated, and was replaced by a coalition of riverine community councils. Official national and international funds were channeled through these community councils and through NGOs for specific development initiatives. Here, as in Buenaventura, "state territorialization" and neoliberal governance were evident in development programs. None of the programs ostensibly designed to address conflict resolution, peace building, and gender-based violence acknowledged the structural factors 
underlying the causes and the racialized and gendered consequences of the Colombian conflict. Black communities had to engage with institutionalized development, and this engagement was reflected in their language, rhetoric, and actions.

On November 21, 2008 I attended a seminar on regional development in Tumaco organized by a group of black and displaced students belonging to the "Desmond Tutu Association of Afro-descendant and Displaced Students" (ASEDAFRO, Asociación de Estudiantes y Desplazados Afrodescendientes de Tumaco Desmond Tutu). The event's sponsors included the University of Nariño, the Mayor's office, local businesses, community organizations such as ASEDAFRO, and national television and radio channels. The flyer for the event identified its key goal as "encouraging, in the general public, the advancement of education, the desire for progress and distinction in every activity, and thereby the ability to become more competitive." It also notes

Competition is the capacity of a person, firm or country to know how to differentiate themselves from their adversaries or competitors, and offer a superior value.

Knowing the importance of competitiveness in globalization and in our daily lives, the students of International Trade and Marketing VII semester have decided to organize the first seminar/workshop "Regional Development and Competitiveness in San Andrés de Tumaco," the only one in the history of the municipality and the extension branch of the University of Nariño... [all translation are the author's]

The seminar was part of the credentialing requirements for a Certificate from the abovementioned program, and smartly dressed young women and men were participating in it to develop the professional skills that their Buenaventura counterparts had expressed a desire to learn.

Among the talks at the seminar were ones that focused on themes such as "sectoral development in Tumaco," "cultural conflict as a problem for effective development initiatives," and "entrepreneurial leadership." Despite the fact that the event was organized by Afro-descendant students inspired by Bishop Tutu, an internationally well-known figure, 
references to global black unity, Afro-Colombian territoriality, or culture practices were absent from the proceedings. The one exception was provided by Leonardo a black social activist and adjunct professor at the University. Originally from the Tumaco region, Leonardo had returned to it after several decades spent studying and working with black struggles further up the coast. Trained in media and communication, he also had his own small NGO, the budget and activities of which were largely defined by a (sub-) subcontract with USAID.

His lecture was entitled, "Culture and Development in the Pacific Coast." Rather than focus on "competitiveness" as such, he surveyed the numerous social and environmental disasters confronting the people of Tumaco: armed violence, murder, drug trafficking, legal and illegal mining, the rise of the oil palm industry, displacement. He noted the extensive commingling of these threats, including the laundering of drug profits by investing in largescale gold mining or hotels and clubs of the sort visible along the beach. Modernization, Leonardo argued, brought trouble as well as benefits to the Tumaco region. As an example, he cited the paving of the Tumaco-Pasto highway, which had allowed for the import of cheap, well-trained manual labor from the Andes at the expense of local labor and for a massive expansion of oil palm plantations.

While Leonardo's NGO ultimately depended on funds trickling down through a chain of contracts from USAID, its activities were still largely his to define. But by my second (2011) visit, economic necessity had forced him to curtail his own projects in favor of contract work with mainstream, U.S.-based, development organizations. These jobs were frustrating for him. Far more bureaucratic and administrative, they were neither grounded in the cultural political realities of the region nor did they have the sense of social urgency he favored and was committed to. A year later he quit such work altogether. While not the only one critical of the institutionalization of Afro-Colombian ethno-territorial rights, Leonardo was among the few resisting it. 
Other meetings in Tumaco revealed that black communities expressed their concerns in the language of mainstream development. At the Tumaco Chamber of Commerce, Executive Director, Zaida Mosquera Patterson, spoke at length about the promise and challenges facing the local fishing industry. She observed that the national government had spent large sums trying to better the lives of local fisher folk, but that such funds rarely yielded good results. The explanation, according to Mosquera Patterson, was to be found in both general mismanagement and a lack of comprehension of local realities, from low educational levels to the unavailability of ice. In 2008, the cost of ice (vital to any expansion of the industry beyond the city) was prohibitive for nearly all would-be fishing entrepreneurs; the Chamber of Commerce was seeking funds for a municipal ice facility such as that installed in Riohacha on the Atlantic Coast. Mosquera Patterson's office was also studying fish-farming methodologies from Beijing and Ecuador and hoping to adapt them for Tumaco. She pointed, however, to a cautionary tale from the 1980s, when Tumaco's first experiment with commercial aquaculture — shrimp farming — collapsed after the introduction of shrimp larvae from Ecuador. The larvae proved to be infected with white spot disease, which has since become endemic in Tumaco.

"We have to fish responsibly," she told me, "or there will be consequences. The fisheries will end." And with it the basis for development, she continued. "We are fostering a management vision in the fishermen so that they can set prices and compete in the market. But management training is not enough. We also need technology, machines, and equipment."

Such development-speak was to be expected from an official. But I also heard it in riverine communities. A local fisherman present at the conversation with Mosquera Patterson spoke of the popular hope that the Tumaco fishing industry would develop differently from that of nearby Ecuador, where short-sighted practices had resulted in steep declines of wild 
and native fish. "Here the young people are learning traditional fishing practices. We can make it work. We just need markets for it." During a visit to the same fisherman's riverine community the previous day, members of the local cooperative reiterated the need for funds for infrastructure development and connections with markets, while lamenting the state's neglect of the region and aid workers' ignorance of local cultural and political realities. Here, as in a poor neighborhood in Tumaco, community members simultaneously expressed immense pride in their culture and territorial connections while stating their need for help with their most pressing needs - economic development, health care, and education.

Contradictions abound in the choices facing Tumaco's poor. Among the most stark are those surrounding coca cultivation and the vexing search for alternatives. Rural communities in the Tumaco area have been profoundly affected by U.S.-sponsored coca eradication schemes. Labeled "selective fumigation" in the official pronouncements of Plan Colombia, these campaigns have often been nearly indiscriminate, rendering wide areas unsuitable for agriculture. As coca migrated from the Putumayo region to Tumaco, eradication measures followed in its footsteps, along with a trickle of USAID funds for "alternative development." Monte Bravo, a USAID-funded project subcontracted to a US development firm Associates in Rural Development (ARD) is one such project. Managed from Bogotá, Monte Bravo sought to develop alternatives to coca by focusing on recovering traditional crops such as plantains and cacao in the rural communities along the coast from southern Buenaventura to Tumaco. But as Ramon [pseudonym] a longtime activist in the southern Pacific region who worked with Monte Bravo explained, such work was fraught with problems: the jockeying for territory by guerillas and paramilitary groups all along these territories, continued fumigation which destroyed any crops planted by the communities, and expanding oil palm plantations. Like Leonardo and other long-term Pacific hands, Ramon noted that 
development bureaucrats in Bogotá or beyond had little understanding of black struggles or realities.

In 2011, Ramon reiterated these critiques. The trickle of economic assistance from USAID, he told me, came with two basic conditions. First, farms had to be smaller than four hectares. Second, they had to be entirely free of coca. For small farmers, however, coca was by far the most profitable crop. With little or no market for other products, these smallholders faced a Catch-22: abstain from coca and try to better one's situation by participating in problematic and insufficient alternative development projects, or plant coca and lose access to such support altogether, while risking fumigation and displacement.

Where fumigation and violence have driven smallholders away, oil palm plantations have frequently followed. The resulting cycle — coca planting in lieu of real alternatives, fumigation, displacement, grabbing of the land for oil palms — was repeated again and again in the Tumaco region. Ramon (and many others I spoke with in Tumaco) saw this process of deterritorialization as a deliberate policy.

Development initiatives from "on high"- dreamed up and directed from the national capital, or from abroad — were routinely critiqued by Tumaqueño activists as ignorant of local realities, unconcerned with Afro-Colombian traditions and practices, or simply racist in their design and execution. But here as in Buenaventura, the choices black activists face are overdetermined. Intractable violence and rapid economic changes have circumscribed the daily lives and livelihoods of black communities, and attempts to keep alive broader ethnoterritorial struggles.

Among PCN activists in Buenaventura, collaboration with institutional development advanced alongside frequent and passionate reference to a different cosmovisión and black autonomous politics. Alternatives, including ethno-cultural models of development, were not a matter of indifference to Tumaqueños. But in a context of far greater deprivation and danger 
and few national and international alliances, the pressure to engage with institutional development was more evident among Afro-Colombian groups and communities in Tumaco.

\section{Concluding Remarks}

The forests, rivers and extensive coastline of the Colombian Pacific lowlands have been the target of overlapping political economic and cultural processes since colonial times. The adoption of a new Constitution in 1991 replaced the Cold War logic of political modernization (including political forestry) in Colombia and ushered in what Devine and Baca (this volume) describe as a fourth moment of political forestry. Stressing the importance of diffusing state power, this moment is characterized by "neoliberal governance" or what Alvarez et al. (2017) call the "civil society agenda." This agenda is framed by "neoliberal economic" reforms outlined in the "Washington Consensus," "neoliberal conservation" following the discourses of sustainable development and biodiversity conservation that emerged at the 1992 UNCED conference and "neoliberal multiculturalism" informed by international accords such as ILO 169. In the 1990s, the Pacific region and its people became a renewed target of the state's modernization agenda. The neoliberal logic of free markets and the 1991 Constitution's call for decentralization and democratic expansion ironically served to expand the power and presence of the Colombian state in the region (Asher and Ojeda 2009).

But forested lands are seldom empty, and the processes through which the state asserts its power are hardly seamless. In the Pacific, the predominantly black and indigenous residents drew on neoliberal conservation and multiculturalism to claim the Pacific lowlands as an ethnic homeland and contest the attempts of external entities to define and gain control over the region's land and resources. Indeed across Latin America, "neoliberal multiculturalism” (Rivera-Cusicanqui 2012; Hale 2002) emerged partly as a response to claims of rights, resources, and representation by Afro-descendants and Indigenous 
movements. Black ethno-territorial struggles then intertwined with, and not just opposed to, the political economic interventions in the Pacific. In the 1990s they shaped and constituted each other, albeit unequally (Asher 2009).

Such "contentious co-productions" of the ecologically and culturally-diverse Pacific lowlands as "political forests" took on new forms when the region became awash with violence in the $21^{\text {st }}$ century. The violence of armed force and the epistemic violence of development facilitated dispossession and opened literal and metaphoric space for the latest phase of capital accumulation. Neoliberal governance rendered nature and culture governable and enabled land grabbing and green grabbing in the Pacific as in other parts of the world (Borras et al. 2011; Devine and Baca, this volume; Fairhead et al. 2012). Local communities faced death and displacement, and the struggles for their lives, lands and livelihoods fragmented and fractured. But black communities and movements continued their resistance and created and took advantage of the gaps in the logic of this phase of governmentality to assert their ethno-territorial claims. But the significance of these gaps and the success of black alternatives remains an open question.

In this paper I describe the continuing efforts of Afro-Colombian communities to assert ethno-territorial claims over the region. I outline how these efforts are not only circumscribed by the material violence of civil war but also the epistemic violence of the technical responses to address the consequences of physical violence. Afro-Colombians assert their demands for territorial autonomy and alternative development based on their cosmovisión while simultaneously participating in the institutionalized development they oppose. Their struggles illustrate that "political forests" are seldom just projects of state territorialization nor simply targets of resistance or contestation by non-state entities.

Alvarez et al. (2017) discuss how a perverse confluence of participatory democracy and neoliberal economic prescriptions underlies the "hegemonic though contested set of 
normative and prescriptive assumptions" (p. 2) of the "civil society agenda" in Latin America. These assumptions govern the discourses and territorial politics of states and social movements but with equivocal results. On the one hand, they channel energy into depoliticized and bureaucratized forms of participation where movements have little room for maneuver to assert their demands. On the other hand, "cultural imaginations have access to resources and networks... in interaction with evolving regimes of neoliberal governmentality" (p. 29). These equivocal dynamics are clearly at play in the ethno-territorial struggles over the Pacific lowlands. On the one hand, the ethno-territorial agenda gets subsumed under humanitarian and development assistance and black demands are increasing couched in legal and constitutional terms of human or property rights. On the other hand, even limited "neoliberal multiculturalism" enables black movements to connect with their counterparts and make alliances nationally, regionally, and globally. It is through translocal and transnational linkages that Afro-Colombian movements keep alive alternative ethnoterritorial imaginaries of the Pacific lowlands. Neither their goal of autonomous territorial control over the region nor the state's territorialization of power is fully realized. This suggests once more that development, including the constitution of political forests, is better understood beyond binary frames of domination and resistance, and more as an always, ongoing co-constitution on uneven terrains of power.

Acknowledgements: I am grateful to Jennifer Devine and Jennifer Baca for their intellectual and logistical labor in organizing the panels on "Political Forests," and for putting this special issue together. Colleagues at the Five College Women's Studies Research Center, the Women, Gender and Sexual Studies department at UMass, and Robert Redick read various versions of the manuscript and gave critical and constructive comments. Thanks also to the Antipode team, and three anonymous reviewers for their feedback.

The luchas of compañer@s in the Pacific lowlands continue to inspire me and keep me honest.

\section{References}

Alvarez S, Baiocchi G, Laó-Montes A, et al. (2017) Interrogating the civil society agenda, reassessing uncivic political activism: An introduction. In: Alvarez S, Rubin JW, Thayer M, 
et al. (eds) Beyond Civil Society: Social Movements, Civic Participation, and Democratic Contestation, 1-31. Durham, NC: Duke University Press

Asher K (2009) Black and Green: Afro-Colombians, Development, and Nature in the Pacific Lowlands, Durham, NC: Duke University Press

Asher, K (2017) From Afro-Colombians to Afro-descendants: The trajectory of black social movements in Colombia, 1990-2010. In Alvarez S, et al. (eds) Beyond Civil Society Agenda: Activism, Participation, and Protest in Latin America, 261-290. Durham, NC: Duke University Press

Asher K and Ojeda D (2009) Producing nature and making the state: Ordenamiento territorial in the Pacific lowlands of Colombia. Geoforum 40:(3) 292-302

Barbary O and Urrea F (eds) (2004) Gente Negra en Colombia: Dinámicas sociopolíticas en Cali y el Pacífico. Medellín, Colombia: CIDSE, IRD, and COLCIENCIAS

Borras S J M, Hall R, Scoones I, et al. (2011) Toward a better understanding of global land grabbing: an editorial introduction. Journal of Peasant Studies 38:(2) 209-216

Cárdenas R (2012) Green multiculturalism: articulations of ethnic and environmental politics in a Colombian 'black community'. The Journal of Peasant Studies 39:(2) 309-333

CODHES (Consultoría para los derechos humanos y el desplazamiento) (2006) Boletín de la Consultoría para los Derechos Humanos y el Desplazamiento No. 69. Available at: http://www.codhes.org/index.php?option=com_si\&type=4

CODHES (2011) ¿Consolidación de qué? Informe sobre el desplazamiento, conflicto armado, y derechos humanos en Colombia 2010. Bogotá, Colombia. http://www.codhes.org/index.php?option=com_si\&type $=4$

Defensoría del Pueblo and International Organization for Migration (IOM) (2008) Promotion and Monitoring of Sexual and Reproductive Rights of Women Victims of Forced Displacement with Emphasis on Intra-familiar and Sexual Violence. Bogotá

Devine $\mathrm{J}$ and Baca $\mathrm{J}$ under review. Political forests: Decentering the state in the era of neo-liberal conservation. Special issue ntroduction. Antipode

Elmhirst, R., 2011. Migrant pathways to resource access in Lampung's political forest: Gender, citizenship and creative conjugality. Geoforum, 42(2), pp.173-183

Escobar A (1995) Encountering Development: The Making and Unmaking of the Third World, Princeton: Princeton University Press

Escobar A (2008) Territories of Difference: Place, Movements, Life, Redes, NC: Durham: Duke University Press

Escobar A (2010) Latin America at a crossroads: Alternative modernizations, postliberalism, or postdevelopment? Cultural Studies 24: 1- 65

Escobar A (2018) Designs for the Pluriverse: Radical Interdependence, Autonomy, and the Making of Worlds. NC: Durham: Duke University Press

Fairhead J, Leach M and Scoones I (2012) Green grabbing: a new appropriation of nature? Journal of Peasant Studies 39:(2) 237-261

Grueso L, Rosero C and Escobar A (1998) The process of black community organizing in the southern Pacific Coast region of Colombia. In: Alvarez S, Dagnino E and Escobar A (eds) Cultures of Politics/Politics of Cultures: Re-visioning Latin American Social Movements, 196-219. Boulder, CO: Westview Press

Hale C R (2002) Does multiculturalism menace? Governance, cultural rights and the politics of identity in Guatemala. Journal of Latin American Studies 34:(3) 485-524

Human Rights Watch (2005) Internal Displacement. Colombia: Displaced and Discarded. The Plight of Internally Displaced Persons in Bogotá and Cartagena. Human Rights Watch Report Available at: http://hrw.org/reports/2005/colombia1005/index.htm

Leal C (2015) Conservation memories. Vicissitudes of a biodiversity conservation project in the rainforests of Colombia, 1992-1998. Environmental History 20:(3) 368-395 
Li, T.M 2007. The Will to Improve: Governmentality, Development, and the Practice of Politics. Durham, NC: Duke University Press

Martínez Cortés P (2013) The Victims and Land Restitution laws in Colombia in context: an analysis of the contradictions between the agrarian model and compensation for the victims. Berlin: Forschungs- und Dokumentationszentrum Chile-Lateinamerika (FDCL), Transnational Institute (TNI)

Matthews A S (2011) Instituting Nature: Authority, Expertise, and Power in Mexican Forests, Cambridge, MA: MIT Press

Meertens D (2010) Forced displacement and women's security in Colombia. Disasters 34S2, S147S164

Ng'weno B (2007) Turf Wars: Territory and Citizenship in the Contemporary State, Stanford, CA: Stanford University Press

Nicholls K and Sánchez-Garzoli G (2011) Buenaventura, Colombia: Where free trade meets mass graves. NACLA Report on the Americas July/August

Oslender U (2007) Violence in development: the logic of forced displacement on Colombia's Pacific coast. Development in Practice 17:(6) 752-764

Oslender U (2016) The Geographies of Social Movements: Afro-Colombian Mobilization and the Aquatic Space, Durham, NC: Duke University Press

Peluso N L and Vandergeest P (2001) Genealogies of the political forest and customary rights in Indonesia, Malaysia, and Thailand. The Journal of Asian Studies 60:(3) 761-812

Peluso N L and Vandergeest P (2011) Political ecologies of war and forests: Counterinsurgencies and the making of national nature. Annals of the Association of American Geographers 101:(3) 587-608

Peluso, N L and Purwanto A B (2018) The remittance forest: Turning mobile labor into agrarian capital. Singapore Journal of Tropical Geography 39: 6-36

Rivas N (2004) Ambientalismo y surgimiento de nuevos actores étnicos en el Pacífico Sur. In: Barbary O and Urrea G F (eds) Gente Negra en Colombia: Dinámicas sociopolíticas en Cali y el Pacífico. Medellín, Colombia: CIDSE, IRD, and COLCIENCIAS, 327-344

Rivera Cusicanqui, S (2012). Ch'ixinakax utxiwa: A Reflection on the practices and discourses of decolonization. The South Atlantic Quarterly 111: (1) 95-109

Silva-Castañeda L (2015) What kind of space? Multi-stakeholder Initiatives and the Protection of Land Rights. International Journal of Sociology of Agriculture \& Food 22:(2) 67-83

UNHCR (United Nations High Commission on Refugees) (2010) 2009 Global Trends: Refugees, Asylum-seekers, Returnees, Internally Displaced and Stateless Persons. Geneva: UNHCR

Vandergeest, Pand Peluso, N. L. (2015) Political forests. In R. Bryant (ed.) The International Handbook of Political Ecology, Northampton, MA: Edward Elgar

Velez I (2014) Law of victims and land restitution: Colombia's Aambitious Llaw faces implementation challenges. FIU Law Review 9 (2) 451-483

Wilshusen P R (2003) Territory, Nnature, and culture. Negotiating the boundaries of biodiversity conservation in Colombia's Pacific coastal region. In: Brechin SR, Fortwangler CL, Wilshusen PR, et al. (eds) Contested Nature. Promoting International Biodiversity Conservation with Social justice in the Twenty-first Century. New York: State University of New York Press

Wolford W (2010) This Land Is Ours Now: Social Mobilization and the Meanings of Land in Brazil, Durham, NC: Duke University Press

Zeiderman A (2016) Submergence: Precarious politics in Colombia's future port-city. Antipode 48:(3) 809-831 